\title{
Potential of Tissue-Engineered Ligament Substitutes for Ruptured ACL Replacement
}

\author{
Goulet F.1,2,3, Chabaud S.1,2,4, Simon F.1,2,4, \\ Napa I.D.1,2,4, Moulin V.1,2,4 and Hart D.A. ${ }^{5}$ \\ ${ }^{1}$ Centre LOEX de l'Université Laval, \\ ${ }^{2}$ Génie tissulaire et régénération: LOEX, \\ Centre de recherche FRSQ du Centre hospitalier affilié universitaire de Québec, \\ ${ }^{3}$ Département de réadaptation, \\ ${ }^{4}$ Département de chirurgie, Faculté de médecine, Université Laval, Québec, QC, \\ ${ }^{5}$ McCaig Institute for Bone and Joint Health, University of Calgary, Calgary, Alberta \\ Canada
}

\section{Introduction}

Anatomical descriptions of anterior cruciate ligament (ACL) can be found in Egyptian papyrus scrolls dating back to 3000 BC. Hippocrates (460-370BC) has described knee subluxation with ACL injury. Even today, the ACL of the knee joint is still the frequent target of trauma, especially in the young and active population (Murray, 2009). Rupture of the ACL of knee affects over 175,000 patients a year worldwide (Myer et al., 2004). Such injury often results from twisting or turning the knee while landing (e.g. non-contact rupture), valgus stress (knock-knee position), or hyperextension directly related to contact or collision. (Wu et al., 2010). For unknown reasons, this major knee joint stabilizer fails to heal after suture repair, (Murray et al., 2007). Often, other knee structures are directly affected when partial or complete ACL injuries occur, impairing knee function (Englund et al., 2009). The tibia and femur are more likely to rub against each other, leading to cartilage defects and osteoarthritis. While a variety of rehabilitation protocols have been assessed, rehabilitation doesn't insure long-term maintenance of knee function. The clinical decision to replace a torn ACL is based on the extent of the damage caused by the injury and subsequent functioning of the knee, and the choice of ACL substitute that is grafted is made accordingly (e.g. autograft, allograft, synthetic, or potentially, a tissue engineered autologous construct). The surgery of the ACL is usually performed several weeks after the injury in order to allow the swelling and inflammation to subside, although in some countries the surgical intervention can occur within hours or days of the injury. After the surgery, physical rehabilitation is necessary to strengthen the surrounding muscles, stabilize the knee joint, prevent arthrofibrosis, and restore range of motion.

\subsection{Function of the ACL on the knee joint}

The ACL has both proprioceptive and mechanical functions. It is the first restraint to anterior translation of the tibia. The ultimate tensile load and stiffness of the human femur- 
ACL-tibia complex are $2160 \pm 157 \mathrm{~N}$ and $242 \pm 28 \mathrm{~N} / \mathrm{mm}$, respectively (Dargel et al., 2007; Woo, 2006). The forces applied on the ACL during normal walking are $303 \mathrm{~N}$ or less (Peterson \& Zantop, 2007). The highest loads and strains on the ACL during daily function are quadriceps-powered extension of the knee, moving it from approximately 40 degrees of flexion to full extension (This explains why open kinetic chain exercises are avoided during early phases of rehabilitation). Secondly, the ACL forces the tibia to internally rotate during anterior tibial translation, indicating that the ACL primarily restrains internal rotational moments during anteroposterior translation, (Fukubayashi et al., 1982).

\subsection{Compromised healing of the injured ACL}

In contrast with extra-articular knee ligaments (e.g. the collateral ligaments), the healing of the intra-articular ACL in vivo is poorly understood. A complete tear of the ACL (midsubstance or at the insertion), would not leave a residual structure on which to form a scar. However, a partial tear should leave at least a partial template to form a scar. Interestingly, even if bleeding occurs after ACL injury, no fibrin-platelet plug is observed to form inside the joint, even at the injury site. One possible explanation for this observation is that circulating intra-articular plasmin breaks down the fibrin plug as fast as it can form (Murray, 2009). Recent work has shown that after trauma to the joint, the production of plasmin is upregulated via the increased secretion of urokinase plasminogen activator (Rosc et al., 2002). With the additional circulating plasmin, the fibrin network is quickly destabilized within the joint environment and no fibrin-platelet plug forms. This premature loss of the fibrin-platelet plug would have the significant clinical benefit of preventing overall joint scarring and stiffness (arthrofibrosis) and thus maintenance of joint mobility after injury. As formation of a fibrin-platelet plug is an essential first step for wound healing of musculoskeletal tissue outside the joint, the loss of this fibrin-platelet plug inside the joint may be the key mechanism behind the failure of intra-articular tissues to heal (Murray, 2009).

However, other possibilities likely also exist. In studies of partial injuries to the ACL in either rabbit (Lo et al., in preparation; Heubner et al., in preparation) or sheep models (Heard et al., 2011), the response to injury leads to an inflammation. In fact, a partial injury to one band of the ACL leads to an initial response not dissimilar to that of the MCL at 3 weeks post-injury, which then fails to mature and ultimately fails to lead to functional repair, possibly due to persistent inflammation (Lo et al., in preparation). Thus, the failure of healing (non-union) and laxity observed in the ACL after suture repair may also be attributed to the adverse influence of synovial fluid (Murray et al., 2009; Woo et al., 2000), to alterations in the cellular metabolism after injury (Amiel et al., 1989), and to intrinsic cell deficiencies (Kobayashi et al., 2000). The superior capacity of the MCL to increase its blood supply through angiogenesis and increased flow is essential for ligament healing to occur, and may be the major difference in healing potential between the ACL and MCL (Kobayashi et al, 2000). Several growth factors have been studied in tendons post-surgery. The expression of Aggrecan, Versican, Biglycan, Lumican, Decorin, TGF- $\beta$ and $\beta$-FGF mRNAs have been monitored in vivo, using a rabbit model of flexor tendon injury (Berglund et al., 2006). The role and the mode of interactions between these various factors, as well as the sequential post-traumatic modulation of their expression remain to be defined. However, it is clear that whatever the mechanisms involved, the intra-articular environment is not 
conducive to normal ACL healing, and this also has implications for the incorporation of ACL reconstructions with either natural tissues or tissue engineered tissues.

\subsection{Impact of torn ACL on the knee strength, stability and osteoarthritis (OA)}

Injury to the anterior cruciate ligament (ACL) is regarded as critical to the physiological kinematics of the femoral-tibial joint, with its disruption eventually causing long-term functional impairment. Both the initial trauma and the pathologic motion pattern of the injured knee may result in primary degenerative lesions of the secondary stabilisers of the knee, each of which are associated with the early onset of OA (Von Porat et al., 2004). Consequently, there is a wide consensus that young and active patients may profit from reconstructing the ACL. Several factors have been identified as significantly influencing the biomechanical characteristics and the functional outcome of an ACL reconstructed knee joint. These factors are: (1) individual choice of autologous graft material using either patellar tendon-bone grafts or quadrupled hamstring tendon grafts, or another type of ACL substitute, (2) anatomical bone tunnel placement within the footprints of the native ACL, (3) adequate substitute tension after cyclic graft preconditioning, and (4) graft fixation close to the joint line using biodegradable graft fixation materials that provide an initial fixation strength exceeding those loads commonly expected during rehabilitation. Based on such factors, the literature encourages mid- to long-term clinical and functional outcome assessments after ACL reconstruction (Dargel et al., 2007).

At follow-up, patellofemoral OA is associated with higher activity level, meniscal injury, extension and flexion deficit, and ACL reconstruction. Although risk factors for posttraumatic OA are multifactorial, the primary risk factor that stood out in the study of Neuman et al. (2009), was whether a meniscectomy had been performed. Early activity modification and neuromuscular knee rehabilitation might also have been related to the low prevalence of radiographic knee OA. In patients with ACL injury willing to restrict themselves to moderate activity level to avoid re-injury, initial treatment without ACL reconstruction should be considered. (Neuman et al., 2009). Interestingly, the incidence of OA after an ACL tear appears to be similar whether or not the ACL has been reconstructed (Lohmander et al., 2007; Oiestad et al., 2010; Frobell et al., 2011), possibly due to concurrent injury to other joint structures at the time of the ACL tear. However, quality of life and a return to knee stability is gained by reconstruction, particularly in younger active patients.

\section{Current surgical approaches to restore knee function after $A C L$ injury}

New options for ACL replacement are under development and some clinical studies are in progress (Altman et al., 2008; Murray, 2009). One of these options is tissue engineering of a tissue replacement, but the majority of reconstructions are performed with autologous or allogeneic tissues. By definition, tissue engineering involves a combination of knowledge and skills in biology and in biomechanics (Functional Tissue Engineering Conference Group, 2008). Such multidisciplinary science has opened the door to the conception and fabrication of new biocompatible materials for ACL reconstruction (Woo, 2009). However, independently from the type of ACL substitute chosen, successful reconstruction of the ACL depends on anatomic placement of a graft ligament substitute (Cole et al., 2000). Strength has been and remains a major consideration in the choice of grafts (Frank \& Jackson, 1997). Accurate tunnel placement minimizes graft excursion and impingement against the roof of 
the intercondylar notch. This will result in maximum knee stability and motion (Fineberg et al., 2000; Steiner et al., 2008).

\subsection{Autologous tendon for torn ACL replacement}

Orthopaedic autograft reconstruction of the ligament often uses a bone-to-bone technique for optimal repair (Frank \& Jackson, 1997; Paxton et al., 2009). The central part of the patellar tendon, including bone fragments from the tibia and the femur, or the hamstring tendons is often used as an ACL substitute. Bone-patellar tendon-bone (BPTB) autografts have been proclaimed as the "gold standard" in ACL reconstruction (Woo et al., 2006). Biomechanically, a 10-mm wide BPTB graft has stiffness and ultimate load values of $210 \pm 65$ $\mathrm{N} / \mathrm{mm}$ and $1784 \pm 580 \mathrm{~N}$, respectively (Wilson et al., 1999), which compare well with those of the young human femur-ACL-tibia complex $(242 \pm 28 \mathrm{~N} / \mathrm{mm}$ and $2160 \pm 157 \mathrm{~N}$, respectively), (Woo et al., 2006). It also shows the advantage of having bone blocks available for graft fixation in the osseous tunnels that leads to better knee stability. Unfortunately, ligament creep or laxity is observed post-surgery, adding to the morbidity associated to the partial loss of an healthy tendon, knee chronic pain, loss of motion, knee instability, quadriceps weakness and patella rupture. The mechanisms by which such grafts lose function is not known in detail, but it may involve replacement of the transplanted tissue by a scar-like matrix after neovascularization, infiltration of cells from the intraarticular environment, and a persistent inflammation as a consequence of the surgery. Thus, many orthopedic surgeons conclude that it is clinically highly justified to explore other strategies for ACL replacement.

\subsection{Cadaver allograft ACL implantation}

The use of allograft substitutes (ACL taken from cadavers) overcomes the need for autologous tissues, avoiding donor site morbidity. However, this approach has deficiencies considering the risks of disease transmission, graft rejection, delayed physiologic integration and inflammation (Murray, 2009). Allografts are relatively expensive and their availability might be limited. Nevertheless, patellar tendons taken from cadavers are still used for ruptured ACL replacement, depending on the short- and long-term needs of each patient that is treated. Cadaver allografts are readily strong and they are progressively remodelled by the cells of the host in situ post-grafting.

\section{Essential factors needed to translate tissue engineering into effective treatment modalities}

Over the last fifteen years, tissue engineered ACL substitutes have raised the interest of orthopedic surgeons for obvious reasons. The concept of producing a ligament in vitro solves the issue of morbidity associated with autologous tendon grafts. Depending on the technological approach developed to reconstruct an ACL in vitro, the availability of tissueengineered products widens the spectrum of surgical options and provides a mid- to longterm solution to prevent knee joint instability. However, the features of a tissue engineered ACL depend on the type of biomaterials that compose its scaffold. The potential and the functionality of any reconstructed ligament must be assessed in animal models. This is the critical step to evaluate the feasibility, the viability and the factors of failure associated with all new ACL replacement strategies under development. 


\subsection{Animal models: strengths and limitations}

Rabbit and goat models have been used to assess torn ACL replacement strategies (Xerogeanes et al, 1998). The advantage of the rabbit remains the wide choice of antibodies and biomarkers commercially available to analyze the various constituents of ACL substitutes post-grafting and ex-vivo. The main limitation of this model is its size, and the fact that it doesn't compare with the human knee joint. The goat is larger and the size of its knee joint is close to the human structures. This facilitates development of a pre-clinical protocol for the implantation of a new type of ACL replacement. However, significant differences are observed between the magnitude of force experienced by the goat ACL and its anteromedial and posterolateral bundles when compared with the corresponding human ACL. Nonetheless, the caprine animal model is widely used for ACL characterization in vitro and in vivo (Tischer et al., 2009; Robayo et al, 2011; Tremblay et al, 2011). The most challenging preclinical model to study ACL repair is certainly the dog knee joint. As in humans, spontaneous ACL injuries are frequently observed in large dog knee joints. The medial meniscus is commonly damaged along with the ACL. The canine model also involves several other issues, including early OA development after torn ACL injury (Murray et al., 2006). For this reason, an ACL substitute tested with success in the canine knee joint would certainly indicate serious potential for use in the human knee. As well, success in the canine model could also have veterinary implications for prevention of OA development in valuable companion, working and show animals.

\subsection{Cell-seeded (stem cells, autologous cell sources) or acellular ACL substitutes?}

There are two groups of cell-seeded ACL substitutes: tissues populated with live cells (e.g. BPTB or semitendinous autologous ACL grafts), and grafts containing dead cells (e.g. cadavers allografts). In addition to the risks of immune and/or inflammatory reaction, autologous or allogenic dead cells must be eliminated post-implantation. The cellular debris present in a cell-seeded ACL substitute may slow down or delay its colonization and impair the growth of host cells that migrate into the grafts from the bone insertion sites towards the middle ligament substance. ACL graft vascularization post-implantation might also be delayed by the presence of microstructures that are subjected to an ongoing necrosis process in the implant. ACL substitutes already populated with live autologous cells that will not be rejected by the host have the potential to be quickly regenerated in situ, following neovascularization to restore blood supply, as well as reinnervation.

Interestingly, tissue engineered ACL substitutes can be seeded with live cells before implantation to initiate matrix deposition and remodeling in the tissue. This may enhance the integration of the implant in situ post-grafting. However, the choice of the cells source remains controversial. The use of mesenchymal stem cells (MSC) is an attractive option as these cells have a long lifespan and are not fully differentiated, suggesting that they could be tolerated from one individual to another. The use of human serum instead of serum of animal source, seems to have a direct and a positive effect on the phenotype of human synovium-derived mesenchymal stem cells (MSC), (Tateishi et al., 2008). The results of this study indicated that human serum (HS) is superior for the culture of human MSCs compared with fetal bovine serum (FBS) in terms of cellular expandability, without losing chondrogenic or osteogenic differentiation capacity. Coupled with the advantage in eliminating the potential risk accompanied with the use of xeno-derived materials, pooled, well-characterized HS could be a useful reagent to promote cellular expansion for clinical 
synovial stem cell-based therapy. Nonetheless, the use of a "universal" human cell population for large-scale production of ACL substitutes would be ideal for obvious technical and economic reasons (Hart et al., 2005). Some issues regarding the source of autologous cells present the advantage to be non-immunogenic, but their amplification in vitro could also involve some risks of phenotypic changes.

The source of the MSC is also an issue that needs to be addressed for optimal development of a functional tissue engineered construct for replaced of a ruptured ACL. MSC have been obtained from multiple sources including bone marrow (BM), muscle, synovial membranes (SM), and more recently, from synovial fluid (SF) itself (reviewed in Peng \& Huard, 2003; McGonagle \& Jones, 2008; Chanda et al., 2010; Augello et al., 2010; Fong et al., 2011). Recent studies have indicated that SM-derived MSC are effective in generating tissue engineered constructs that can serve as articular cartilage repair tissues (Ando et al., 2007; Shimomura et al., 2010), but whether such MSC can also serve as effective cells to generate a replacement ACL have not been explored in detail (McGonagle \& Jones, 2008). Very recent studies have shown that porcine (Ando et al., in preparation) and normal human (Krawetz et al., in preparation) SF and SM MSC exhibit very similar properties, so this source may be a preferred population in the future for ACL repair constructs. Why such MSC are present in the SF is not known, but likely they are there to facilitate repair normal repair of microdamage to intraarticular tissues such as cartilage, menisci and ligaments, so they exhibit good potential for tissue engineering purposes.

The use of fibroblasts isolated from skin instead of ACL biopsies to populate tissueengineered ACL substitute led to comparable results in the goat knee joint (Tremblay et al., 2011). The fibroblasts isolated from both sources secrete the same types of collagen (I and III), but a skin microbiopsy is more readily harvested than a tissue sample collected under arthroscopy from a ruptured ACL in an injured knee joint. Ultimately, acellular ACL substitutes made of biodegradable and biocompatible biomaterials remain the safest option. However, such substitutes will have to be colonized by cells from the host postimplantation. Therefore, tissue-engineered acellular ACL substitutes implies a delayed remodeling of the graft (Robayo et al., 2011), which may impair its long-term stability in situ. Cells seem to play an essential role in the development of such tissue in vitro. However, to keep the best of both options, it would be important to proceed in two phases to obtain a viable and efficient ACL substitute. The first phase would be based on the use of cells to structure and strengthen the ligament scaffold in culture. When strong enough to sustain the biomechanical stress in the joint, the ligament could be lyophilized before implantation in order to kill the cells initially present in the implant and allow cell colonization by the host, being sure that the structure of the scaffold will play its role, and thus enhance integration.

\subsection{Biomaterials: synthetic, native or both?}

To facilitate host cell migration, growth, colonization and remodeling of ACL substitutes post-implantation, the scaffold of the graft must be porous and entirely biocompatible. The graft must be biodegradable and the products generated by this degradation should also be readily eliminated through physiological mechanisms. Collagen I is the major and the natural component of the native ACL matrix. Therefore, this protein is highly suitable, alone or in combination with other biocompatible constituents, to build the scaffold of a tissueengineered ACL substitute (Goulet et al., 2004). For example, a collagen-platelet rich plasma 
(collagen-PRP) bridging scaffold, added in a central ACL defect, can stimulate healing of the ACL histologically and biomechanically (Murray et al., 2006; Spindler et al., 2009). Other types of tissue-engineered biomaterial scaffolds have been described for their potential as ACL replacement alternatives, as long as they can be implanted and sustain the biomechanical stress to which they are subjected in vivo (Altman et al., 2008; Sandmann and Tischer, 2010). More recently, the concept of anatomic double bundle ACL reconstruction has been developed to replace antero-medial and postero-lateral bundles of the ACL. Such approach aims at improving the biomechanical functionality of tissue-engineered grafts, even when the knee is subjected to rotatory loads (Woo et al., 2006).

\subsection{Role of biomechanical stimulation in generating an effective tissue-engineered construct}

The main advantage of including living cells in any tissue-engineered ACL substitute is the possibility to stimulate early matrix synthesis and remodelling in the reconstructed tissue in vitro. Cyclic stretching is an example of biomechanical stimuli that increase collagen synthesis by cells in the tissue, thereby strengthening the resultant scaffold made of aligned fibre bundles (Goulet et al., 2000, Kaneko et al., 2009). Thus, the ACL substitute has already reached a first step towards matrix synthesis, and the process can continue to progress in response to the in vivo strains that are applied to the graft in the post-transplantation environment (Goulet et al., 2004).

\subsection{Placement and effective repair of the biomechanical environment}

The anatomic placement of a graft ligament substitute is crucial for its proper integration and functional behavior (Cole et al., 2000). As previously mentioned, accurate tunnel placement should be performed with respect to the original insertion sites of the torn ACL, to limit graft excursion and impingement against the roof of the intercondylar notch, (Fineberg et al., 2000; Steiner et al., 2008). The ACL substitute must be able to resist an initial graft tension ranging from 44 to $88 \mathrm{~N}$ (Woo et al., 2006). An in vivo study on goats found no significant differences in knee kinematics and in situ forces, between high (35 N) and low (5 $\mathrm{N}$ ) initial tension at 6 weeks after surgery (Abramowitch et al., 2003). Viscoelastic studies have revealed that the tension in the graft can decrease by as much as $50 \%$ within a short time after fixation because of its stress relaxation behaviour. Variation in outcomes may also be influenced by additional variables associated with the individual such as age, sex, genetics, obesity, muscle strength, activity, and re-injury. Therefore, a return to joint stability and functional state is the main objective of the clinical management of the knee joint following ACL injury. A tissue-engineered ACL substitute that could stabilize the joint and maintain its functional state post-grafting is certainly needed. However, if the integrity of the grafted material is to continue to function and progress in biomechanical properties, then likely the intra-articular environment will have to be manipulated to limit surgeryinduced inflammation and promote anabolic conditions.

\section{Tissue engineered ACL substitutes assessed in vivo and under development}

Several tissue-engineered ACL substitutes have been proposed in the literature. Crosslinked bovine collagen fibers, chitosan-based hyaluronan hybrid polymer fibers, alginate- 
based chitosan hybrid polymer fibers, polyglycolic acid scaffolds, silk matrix, and other biodegradable scaffolds seeded or not with living cells (Altman et al., 2008). However, presently only ligament augmentation devices have been subjected to clinical trials. In contrast, many biosynthetic and biological ACL substitutes are being assessed in preclinical models. Such is the case with the tissue engineered ACL substitute that was developed using bone blocks, type I collagen and autologous cells (Goulet et al., 2004). The scaffold for this ACL substitute is made of bovine type I collagen that is seeded with autologous fibroblasts isolated from the ACL of the goat to be grafted. This ligament is produced entirely in vitro (Fig.1).

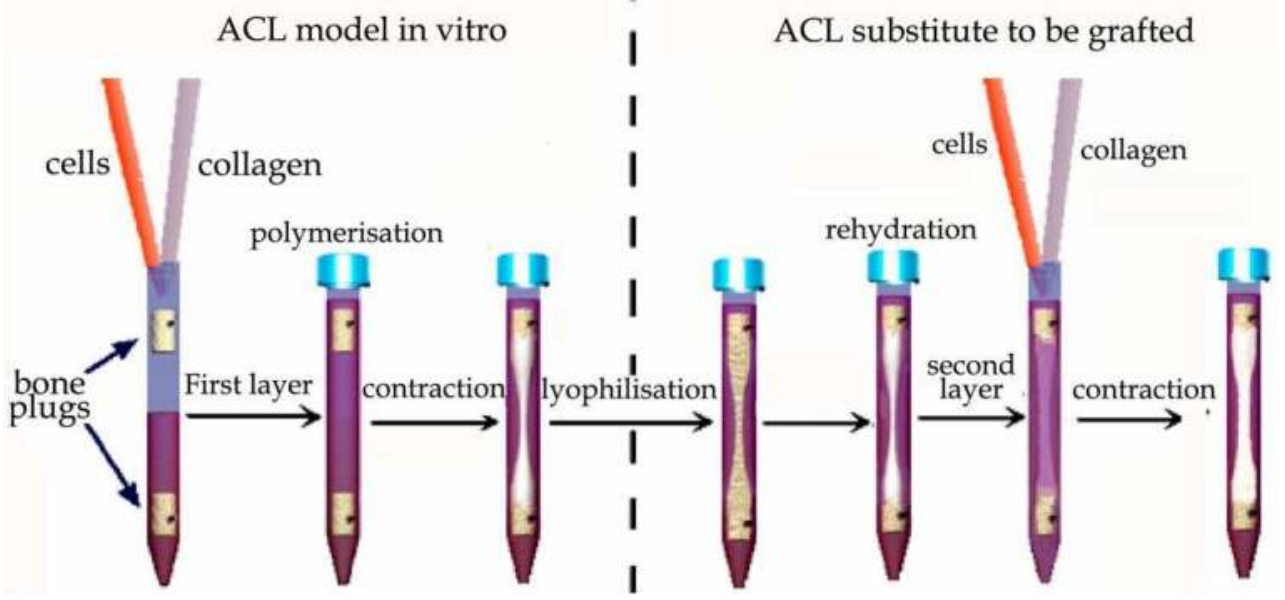

Fig. 1. Steps of production of a tissue engineered ACL substitute

A type I collagen solution $(1 \mathrm{mg} / \mathrm{ml})$, is mixed with autologous fibroblasts $\left(0,5 \times 10^{6}\right.$ cells $/ \mathrm{ml}$ ) in a test tube containing two bone plugs fixed with a pin at the top and at the bottom of it. The collagen polymerizes and is contracted by the cells to obtain a ligament that can be used as an in vitro model. To produce a ligament for implantation into a knee joint, a surgical thread is placed between the bones (not shown). A lyophilization step is then added to obtain a scaffold that is stronger. Once rehydrated, a second layer of collagen including cells is subsequently added to the construct. The collagen polymerizes and the ACL substitute is ready to be grafted into a knee joint.

The ACL substitute is maintained under static tension in culture (Fig.2), with the tension applied by pulling one of the bone plugs in a programmed manner. This process also induces the alignment of the collagen fibers in the direction of the applied tension.



Fig. 2. Tissue engineered ACL substitute 
Macroscopic view of a tissue-engineered ACL substitute maintained in culture for two months under static tension, anchored with two spongious bone plugs. Note the central portion of the tissue that was contracted by the live cells that populate its type I collagen scaffold. A surgical thread, bioresorbed within a month in vivo, reinforces the links between the bones.

The main features that orthopedic surgeons want to know regarding such ACL substitutes produced in vitro are their strength and their stiffness. Rupture assays were performed to evaluate the mechanical properties of the engineered ligament constructs before implantation (Table 1). Any natural collagen gel that is not reinforced using a thread or another type of support cannot resist a tension that is higher than $0.5 \mathrm{~N}$ (Fig3A). Once lyophilized, the collagen scaffold shows an ultimate strength of $2 \mathrm{~N}$ (Fig.3B), while the addition of a bioresorbed surgical thread will allow the structure to resist a tensile load of more than $60 \mathrm{~N}$.

\begin{tabular}{|c|c|c|}
\hline Structure of the matrix & Ultimate strength (N) & $\begin{array}{l}\text { Location of the } \\
\text { rupture site }\end{array}$ \\
\hline $\begin{array}{l}1 \text { layer of hydrated } \\
\text { collagen (gel) }\end{array}$ & $0.2-0.5(+5 \%)$ & $\begin{array}{l}\text { Interface bone- } \\
\text { ligament }\end{array}$ \\
\hline $\begin{array}{l}+1 \text { layer of hydrated } \\
\text { collagen lyophilized } \\
\text { (rehydrated) }\end{array}$ & $2(+5 \%)$ & $\begin{array}{l}\text { Middle of the } \\
\text { ligament }\end{array}$ \\
\hline $\begin{array}{l}+1 \text { layer of hydrated } \\
\text { collagen lyophilized } \\
\text { (rehydrated) around a } \\
\text { resorbable surgical } \\
\text { thread: Maxon } 3.0 \text { ) }\end{array}$ & $\begin{array}{c}>60 \mathrm{~N} \text { (grafted in goat } \\
\text { knee joint) }\end{array}$ & Not determinated \\
\hline
\end{tabular}

Averaged cross-sectional area surface: $100 \mathrm{~mm}^{2}(+5 \%)$

$\mathrm{N}=$ Newton

Table 1. Averaged ultimate strength values $(n=12)$ of ex-vivo ACL grafts $(n=6)$

The tissue-engineered ACL was grafted into goat knee joints for periods varying from one to 13 months (Goulet et al., 2004; Robayo et al, 2011; Tremblay et al, 2011). An immobilising plaster cast was placed on the leg during the first week post-surgery to limit motion (to favour healing) and to prevent the goat from irritating the wound (Fig.4A). Following removal of the cast, the goats gradually returned to putting weight on the affected leg, walking freely thereafter (Fig.4B).

Such implant is vascularized within a month in situ post-grafting. Nerve endings, Sharpey's fibers, and fibrocartilage were observed in all of the grafts at six months post-implantation $(n=3)$. Electron microscopic analyses demonstrated that the diameter of the collagen fibers synthesized by the cells in vivo, were comparable with native ACL fibers (Goulet et al., 2004). One of the issues that could impede the potential use of this ACL substitute for clinical application would be the difficulty to harvest a torn ACL biopsy to isolate the cells 
that are required. Recently, experiments conducted with tissue engineered ACLs seeded with autologous skin fibroblasts and grafted in goat knee joints for six months led to the same observations that were made with ACL cells (Fig.5). Thus, animal experimentation using skin fibroblasts has also shown promising signs of integration into the goat knee joint (Tremblay et al., 2011). Interestingly, analyses by zymography demonstrated that caprine and human fibroblasts, isolated from ACL and skin biopsies, secrete the same types of gelatinases (collagenases), suggesting that they share similar potential for collagen remodeling (data not shown).
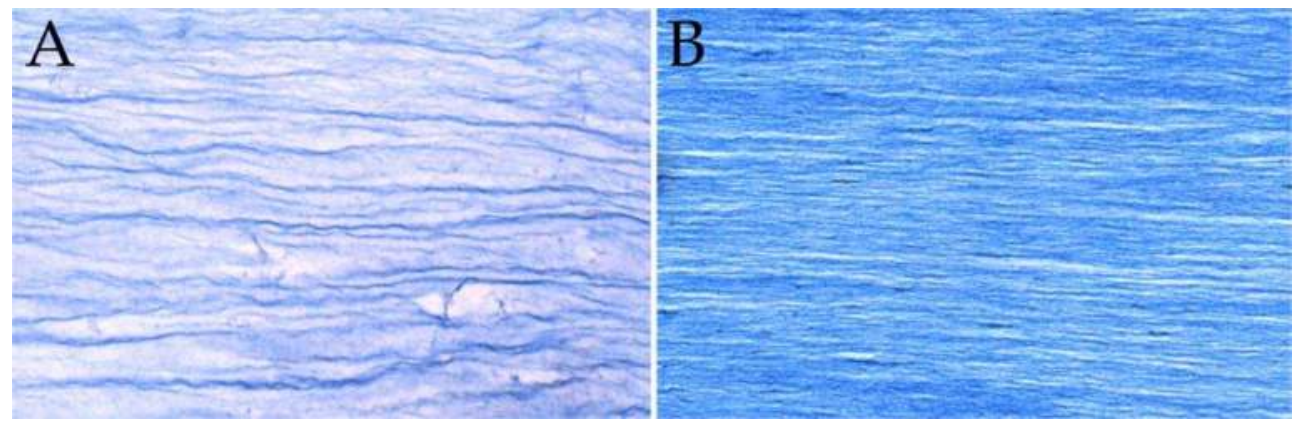

Fig. 3. Collagen scaffolds of a tissue engineered ACL subjected to static tension in culture. Photomicrographs of histological microsections of the type I collagen scaffold of tissueengineered ACL stained with the Trichrome de Masson's method. Note the good alignment of the collagen fibers that was induced by the horizontal tension applied on the tissue for 24 hrs in culture. Shortly after collagen polymerization, the density of the fibers in the tissueengineered scaffold is low (A). After lyophilisation and rehydration of the scaffold, the collagen fibers become closer to each other, leading to an increased matrix density and strength. $(\times 60)$


Fig. 4. A goat grafted with an autologous tissue-engineered ACL.

Photograph of a goat three days (A) and one month (B) after the implantation in the right knee joint of a tissue-engineered ACL seeded with autologous fibroblasts. The animal could jump and run only one month post-implantation 



Fig. 5. Implantation of a tissue engineered ACL substitute in a goat knee joint.

Macroscopic view of a tissue-engineered ACL substitute at the time of implantation (A) and six months later (B). The articular cartilage didn't show any sign of degeneration before and after tissue-engineered ACL implantation

\section{Conclusions}

The fundamental and clinical issues associated with the management of torn ACL replacement remain those that were described by Frank and Jackson (1997) fifteen years ago. Back then, the concept of an effective tissue-engineered ligament for permanent ACL replacement was a new and exciting distant possibility. Today, such a concept is a very realistic outcome, with the evolution of nanotechnology, combined with a wider spectrum of biomaterials developed through interdisciplinary skills and know-how (Functional Tissue Engineering Conference Group, 2008). The development of tissue-engineered ACLs in vitro presents several advantages for the patients and for the orthopaedic surgeons. It avoids healthy tissue morbidity and thus, reduces the period of rehabilitation post-surgery. It allows the production of a substitute that has the proper length, diameter and scaffold to fit the joint and stabilize it. The modulation of matrix fibers in vitro by mechanical stimulation, cell-matrix interactions and structural modifications of the scaffold, are good indicators that the tissue-engineered ACL substitute will become a viable surgical option in a very near future.

However, generation of an effective engineered ACL replacement that can withstand the in vivo loading environment is only a critical first step in a process. Implantation and postimplantation events are also critical to sustain the potential of such engineered constructs, and these include correct placement of the grafts to mimic normal loading patterns, as well as controlling the intraarticular environment of minimize the catabolic influence of persistent inflammation and maximizing the anabolic activities in this compartment. Such control could contribute to the long-term effectiveness of the constructs via prevention of loss of function via alteration of their creep properties and prevention of conversion to a structure with scar-like properties. With such control, knee function can be restored and risk for OA development later in life may be abrogated. 


\section{Acknowledgment}

The authors gratefully acknowledge the collaboration of Dr. Réjean Cloutier and Dr. Jean Lamontagne, orthopaedic surgeons, and the financial support of the Natural Sciences and Engineering Research Council of Canada (NSERC), Canadian Institutes of Health Research (CIHR), The Arthritis Society, the Alberta Innovates Health Solutions OA Team Grant, the Alberta Foundation for Medical Research, and the Réseau ThéCell, FRSQ.

\section{References}

Abramowitch, S.D.; Papageorgiou, C.D.; Withrow, J.D.; Gilbert, T.W. \& Woo, S.L. (2003). The effect of initial graft tension on the biomechanical properties of a healing ACL replacement graft: a study in goats. Journal of Orthopaedic Research, Vol.21, No.4, (July 2003), pp. 708-715, ISSN 0736-0266

Altman, G.H.; Horan, R.L.; Weitzel, P. \& Richmond, J.C. (2008). The use of long-term bioresorbable scaffolds for anterior cruciate ligament repair. The Journal of the American Academy of Orthopaedic Surgeons, Vol.16, No.4, (April), pp. 177-187, ISSN 1067-151X

Amiel, D.; Ishizue, K.K.; Harwood, F.L.; Kitabayashi, L. \& Akeson, W.H. (1989). Injury of the anterior cruciate ligament: the role of collagenase in ligament degeneration. Journal of Orthopaedic Research, vol.7, No.4, pp. 486-493, ISSN 0736-0266

Ando, W.; Tateishi, K.; Hart, D.A.; Katakai, D.; Tanaka, Y.; Takata, K.; Hashimoto, J.; Fugie, H.; Shino, K.; Yoshikawa, H. \& Nakamura, N. (2007). Cartilage repair using an in vitro generated scaffold-free tissue-engineered construct derived from porcine synovial mesenchymal stem cells. Biomaterials, Vol.28, No.36, (December), pp. 54625470, ISSN 0142-9612

Augello, A.; Kurth, T.B. \& DeBari, C. (2010). Mesenchymal stem cells: a perspective from in vitro cultures to in vivo migration and niches. European Cells and Materials, Vol.20, (September), pp. 121-133, ISSN 1473-2262

Berglund, M.; Reno, C.; Hart, D.A. \& Wiig, M. (2006). Patterns of mRNA expression for matrix molecules and growth factors in flexor tendon injury: Differences in the regulation between tendon and tendon sheath. The Journal of Hand Surgery, Vol.31A, No.8, (October), pp. 1279-1287, ISSN 1753-1934

Cole, J.; Brand, J.C. Jr; Caborn, D.N. \& Johnson, D.L. (2000). Radiographic analysis of femoral tunnel position in anterior cruciate ligament reconstruction. American Journal of Knee Surgery, Vol.13, No.4, (April), pp. 218-222, ISSN 0899-7403

Chanda, D.; Kumar, S. \& Ponnazhagan, S. (2010). Therapeutic potential of adult bone marrow-derived mesenchymal stem cells in diseases of the skeleton. Journal of Cellular biochemistry, Vol.111, No.2, (october), pp. 249-257, ISSN 0730-2312

Dargel, J.; Gotter, M.; Mader, K.; Pennig, D.; Koebke, J. \& Schmidt-Wiethoff, R. (2007). Biomechanics of the anterior cruciate ligament and implications for surgical reconstruction. Strategies in Trauma and Limb Reconstruction, Vol.2, No.1, (April), pp. 1-12, ISSN 1828-8936

England, M.; Guermazi, A. \& Lohmander, S.L. (2009). The role of the meniscus in knee osteoarthritis: a cause or a consequence. Radiologic Clinics of North America, Vol.47, No.4, (July), pp. 703-712, ISSN 0033-8389 
Fineberg, M.S.; Zarins, B. \& Sherman, O.H. (2000). Practical considerations in anterior cruciate ligament replacement surgery. Arthroscopy, Vol.16, No.7, (October), pp.715724, ISSN 0749-8063

Fong, E.L.; Chan, C.K. \& Goodman, S.B. (2011). Stem cell homing in musculoskeletal injury. Biomaterials, Vol.32, No.2, (January), pp. 395-409, ISSN 0142-9612

Frank, C.B. \& Jackson, D.W. (1997). The science of reconstruction of the anterior cruciate ligament. Journal of Bone and Joint Surgery, Vol.79, No.10, (October), pp. 1556-1576, ISSN 00219355

Frobell, R.B.; Roos, E.M.; Roos, H.P.; Ranstam, J. \& Lohmander, L.S. (2010). A randomized trial of treatment for acute anterior cruciate ligament tears. The New England Journal of Medicine. Vol.363, Vol.4, (July), pp. 331-342, ISSN 0028-4793

Functional Tissue Engineering Conference Group. (2008). Evaluation Criteria for Musculoskeletal and Craniofacial Tissue Engineering Constructs: A conference Report. Tissue Engineering (part A), Vol.12, No.4, (December), pp. 2089-2104, ISSN 1937-3368

Fukubayashi, T.; Torzilli, P.A.; Sherman, M.F. \& Warren, R.F. (1982). An in vitro biomechanical evaluation of anterior-posterior motion of the knee. Tibial displacement, rotation, and torque. The Journal of Bone Joint Surgery (American volume), Vol.64, No.2, (February), pp. 258-264, ISSN 0021-9355

Goulet, F.; Rancourt, D.; Cloutier, R.; Germain, L.; Poole, A.R. \& Auger, F.A. (2000). Tendons and ligaments. In Principles of Tissue Engineering (2nd Ed.).(R. Lanza, R. Langer and J.Vacanti, Eds). Academic Press Ltd, San Diego, pp. 711-722, ISBN 978-0-12-3706157

Goulet, F.; Rancourt, D.; Cloutier, R.; Tremblay, J.; Bouchard, M.; Stevens, L.-M.; Labrosse, J.; Dupuis, D.; Lamontagne, J. \& McKee, M. (2004). Implantation of bioengineered anterior cruciate ligament substitutes: histological, ultrastructural and biomechanical analyses. Applied Bionics and Biomechanics, Vol.1, No.2, pp. 115-121, ISSN 1176-2322

Hart, D.A.; Shrive, N.G. \& Goulet, F. (2005). Tissue engineering of ACL replacements. Sports Medicine and Arthroscopy Review, Vol.13, No.3, (September), pp. 170-176, ISSN 10628592

Heard, B.J.; Achari, Y.; Chung, M.; Shrive, N.G. \& Frank, C.B. (2011). Early joint tissue changes are correlated with a set of inflammatory and degradative synovial biomarkers at ACL autograft and its sham surgery in an ovine model. Journal of Orthopaedic Research, (March 8), [E-pub ahead of print], ISSN 0736-0266

Kaneko, D.; Sasazaki, Y.; Kikuchi, T.; Ono, T.; Nemoto, K.; Matsumoto, H. \& Toyama, Y. (2009). Temporal Effects of Cyclic Stretching on Distribution and Gene Expression of Integrin and Cytoskeleton by Ligament Fibroblasts In Vitro. Connective Tissue Research, Vol.50, No.4, pp. 263-269, ISSN (printed): 0300-8207, ISSN (electronic) 1607-8438

Kobayashi, K.; Healey, R.M.; Sah, R.L.; Clark, J.J.; Tu, B.P.; Goomer, R.S.; Akeson, W.H.; Moriya, H. \& Amiel, D. (2000). Novel method for the quantitative assessment of cell migration: a study on the motility of rabbit anterior cruciate (ACL) and medial collateral ligament (MCL) cells. Tissue Engineering, Vol.6, No.1, (February), pp. 2938, ISSN 2152-4847 
Lohmander, L.S.; Englund, P.M.; Dahl, L.L. \& Roos, E.M. (2007). The Long-term Consequence of Anterior Cruciate Ligament and Meniscus Injuries: Osteoarthritis. The American Journal of Sports Medicine, Vol.35, No.10, (October), pp. 1756-1769, ISSN 0363-5465

McGonagle, D. \& Jones, E. (2008). A potential role for synovial fluid mesenchymal stem cells in ligament regeneration. Rheumatology, Vol.47, No.8, (August), pp. 1114-1116, ISSN 1462-0324

Myer, G.D.; Ford, K.R. \& Hewett, T.E. (2004). Rationale and clinical techniques for anterior cruciate ligament injury prevention among female athletes. Journal of Athletic Training, Vol.39, No.4, (December), pp. 352-364, ISSN 1062-6050

Murray, M.M. (2009). Current status and potential for primary ACL repair. Clinics in Sports Medicine, Vol.28, No.1, (January), pp. 51-61, ISSN 0278-5919

Murray M.M., Spindler KP, Devin C, Snyder BS, Muller J, Takahashi M, Ballard P, Nanney LB, Zurakowski D. (2006). Use of a collagen-platelet rich plasma scaffold to stimulate healing of a central defect in the canine ACL. Journal of Orthopaedic Research, Vol.24, No.4, (April), pp. 820-830, ISSN: 0736-0266

Murray, M.M.; Spindler, K.P.; Abreu, E.; Muller, J.A.; Nedder, A.; Kelly, M.; Frino, J.; Zurakowski, D.; Valenza, M.; Snyder, B.D. \& Connolly, S.A. (2007). Collagenplatelet rich plasma hydrogel enhances primary repair of the porcine anterior cruciate ligament. Journal of Orthopaedic Research, Vol.25, No.1, (January), pp. 81-91, ISSN: 0736-0266

Neuman, P.; Kostogiannis, I.; Fridén, T.; Roos, H.; Dahlberg, L.E. \& Englund, M. (2009). Patellofemoral osteoarthritis 15 years after anterior cruciate ligament injury - a prospective cohort study. Osteoarthritis and Cartilage, Vol.17, No.3, (March), pp. 284290, ISSN 1063-4584

Oiestad, B.E.; Holm, I.; Aune, A.K.; Gunderson, R.; Myklebust, G.; Engbretsen, L.; Fosdahl, M.A. \& Risberg, M.A. (2010) Knee function and prevalence of knee osteoarthritis after anterior cruciate ligament reconstruction: a prospective study with 10 to 15 years of follow-up. The American Journal of Sports Medicine, Vol.38, No.11, (July), pp. 2201-2210, ISSN 0363-5465

Paxton, J.Z.; Donnelly, K.; Keatch, R.P. \& Baar, K. (2009). Engineering the bone-ligament interface using polyethylene glycol diacrylate incorporated with hydroxyapatite. Tissue Engineering (Part A), Vol.15, No.6, (June), pp. 1201-1209, ISSN 1937-3368

Peng, H. \& Huard, J. (2003). Stem cells in the treatment of muscle and connective tissue diseases. Current Opinion in Pharmacology, Vol.3, No.3, (June), pp. 329-333, ISSN 1471-4892

Petersen, W. \& Zantop, T. (2007). Anatomy of the anterior cruciate ligament with regard to its two bundles. Clinical Orthopaedics and Related Research, Vol.454, (January), pp. 35-47, ISSN 0009-921X

Robayo, L.M.; Moulin, V.; Tremblay, P.; Cloutier, R.; Lamontagne, J.; Larkin, A.-M.; Chabaud, S.; Simon, F.; Islam, N. \& Goulet, F. (2011). New ligament healing model based on tissue-engineered collagen scaffolds. Wound Repair and Regeneration, Vol.19, No.1, (January), pp. 38-48, ISSN 1067-1927

Rosc, D.; Powierza, W.; Zastawna, E.; Drewniak, W.; Michalski, A. \& Kotschy, M. (2002). Post-traumatic plasminogenesis in intraarticular exudate in the knee joint. Medical Science Monitor, Vol.8, No.5, (May), pp. CR371-CR378, ISSN 1234-1010 
Sandmann, G.H. \& Tischer, T. (2010). Tissue engineering of the anterior cruciate ligament and meniscus using acellularized scaffolds. In Tissue engineering (D. Eberli, Ed.). pp. 437-458, InTech, ISBN 978-953-307-079-7

Shimomura, K.; Ando, W.; Tateishi, K.; Nansai, R.; Fujie, H.; Hart, D.A.; Kohda, H.; Kita, K.; Kanamoto, T.; Mae, T.; Nakata, K.; Shino, K.; Yoshikawa, H. \& Nakamura, N. (2010). The influence of skeletal maturity on allogenic synovial mesenchymal stem cell-based repair of cartilage in a large animal model. Biomaterials, Vol.31, No.31, (November), pp. 8004-8011, ISSN 0142-9612

Spindler, K.P.; Murray, M.M.; Carey, J.L.; Zurakowski, D. \& Fleming, B.C. (2009). The Use of Platelets to Affect Functional Healing of an Anterior Cruciate Ligament (ACL) Autograft in a Caprine ACL Reconstruction Model. The Journal of Orthopaedic Research, Vol.27, No.5, (May), 631-638, ISSN 0736-0266

Steiner, M.E.; Murray, M.M. \& Rodeo, S.A. (2008). Strategies to improve anterior cruciate ligament healing and graft placement. The American Journal of Sports Medicine, Vol.36, No.1, (January), pp. 176-189, ISSN 0363-5465

Tateishi,K.; Ando, W., Higuchi, C.; Hart, D.A.; Hashimoto, J.; Nakata, K.; Yoshikawa, H. \& Nakamura N. (2008). Comparison of human serum with fetal bovine serum for expansion and differentiation of human synovial MSC: Potential feasibility for clinical applications. Cell Transplantation, Vol.17, No., (5), (January), pp. 549-557, ISSN 0963-6897

Tischer, T.; Ronga, M.; Tsai, A.; Ingham, S.J.M.; Ekdahl, M.; Smolinski, P. \& Fu, F.H. (2009). Biomechanics of the goat three bundle anterior cruciate ligament. Knee Surgery, Sports Traumatology, Arthroscopy, Vol.17, No.8, (August), pp. 935-940, ISSN 09422056

Tremblay, P.; Cloutier, R.; Lamontagne, J.; Belzil, A.-M.; Larkin, A.-M.; Chouinard, L.; Chabaud, S.; Laverty, S.; Lussier, B. \& Goulet, F. (2011). Potential of skin fibroblasts for application to anterior cruciate ligament tissue engineering. Cell Transplantation, Vol.20, No.X, pp. XX-XX (In press), ISSN 0963-6897

Wilson TW, Zafuta MP, Zopitz M: (1999). A biomechanical analysis of matched bonepatellar-tendon-bone and double-looped semitendinosus and gracilis tendon grafts. The American Journal of Sports Medicine, Vol.27, No.2, (Mars-April), pp. 202-207, ISSN 0363-5465

von Porat, A.; Roos, E.M. \& Roos, H. (2004). High prevalence of osteoarthritis 14 years after an anterior cruciate ligament tear in male soccer players: a study of radiographic and patient relevant outcomes. Annals of the Rheumatic Diseases, Vol.63, No.3, (March), pp. 269-273, ISSN 0003-4967

Woo, S.L.; Vogrin, T.M. \& Abramowitch, S.D. (2000). Healing and repair of ligament injuries in the knee. Journal of the American Academy of Orthopaedic Surgeons, Vol.8, No.6, (November-December), pp. 364-372, ISSN 1067-151X

Woo, S. L.-Y.; Wu, C.; Dede, O.; Vercillo, F. \& Noorani, S. (2006). Biomechanics and anterior cruciate ligament reconstruction. Journal of Orthopaedic Surgery and Research, Vol.1, (September 25), pp. 2, ISSN 1749-799X

Woo, S.L.-Y. (2009). Tissue engineering: use of scaffolds for ligament and tendon healing and regeneration. Knee Surgery Sports Traumatology Arthroscopy, Vol.17, No.6, pp. 559-560, ISSN 0942-2056 
Wu, J.L.; Seon, J.K.; Gadikota, H.R.; Hosseini, A.; Sutton, K.M.; Gill, T.J. \& Li, G. (2010). In situ forces in the anteromedial and posterolateral bundles of the anterior cruciate ligament under simulated functional loading conditions. American Journal of Sports Medicine, Vol.38, No.3, (March), pp. 558-563, ISSN 0363-5465

Xerogeanes, J.W.; Fox, R.J.; Takeda, Y.; Kim, H.S.; Ishibashi, Y.; Carlin, G.J. \& Woo, S.L. (1998). A functional comparison of animal anterior cruciate ligament models to the human anterior cruciate ligament. Annals of Biomedical Engineering, Vol.26, No.3, (May-June), pp. 345-352, ISSN 0090-6964 


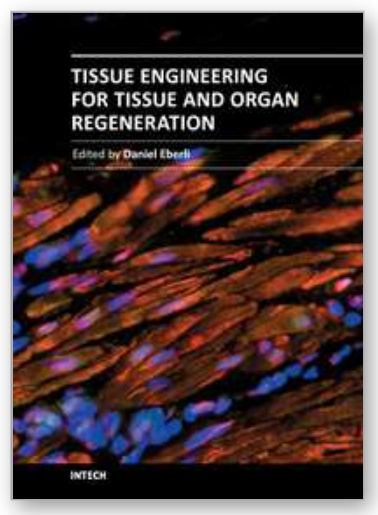

\author{
Tissue Engineering for Tissue and Organ Regeneration \\ Edited by Prof. Daniel Eberli
}

ISBN 978-953-307-688-1

Hard cover, 454 pages

Publisher InTech

Published online 17, August, 2011

Published in print edition August, 2011

Tissue Engineering may offer new treatment alternatives for organ replacement or repair deteriorated organs. Among the clinical applications of Tissue Engineering are the production of artificial skin for burn patients, tissue engineered trachea, cartilage for knee-replacement procedures, urinary bladder replacement, urethra substitutes and cellular therapies for the treatment of urinary incontinence. The Tissue Engineering approach has major advantages over traditional organ transplantation and circumvents the problem of organ shortage. Tissues reconstructed from readily available biopsy material induce only minimal or no immunogenicity when reimplanted in the patient. This book is aimed at anyone interested in the application of Tissue Engineering in different organ systems. It offers insights into a wide variety of strategies applying the principles of Tissue Engineering to tissue and organ regeneration.

\title{
How to reference
}

In order to correctly reference this scholarly work, feel free to copy and paste the following:

Goulet F., Chabaud S., Simon F., Napa I.D., Moulin V. and Hart D.A. (2011). Potential of Tissue-Engineered Ligament Substitutes for Ruptured ACL Replacement, Tissue Engineering for Tissue and Organ Regeneration, Prof. Daniel Eberli (Ed.), ISBN: 978-953-307-688-1, InTech, Available from:

http://www.intechopen.com/books/tissue-engineering-for-tissue-and-organ-regeneration/potential-of-tissueengineered-ligament-substitutes-for-ruptured-acl-replacement

\section{INTECH}

open science | open minds

\author{
InTech Europe \\ University Campus STeP Ri \\ Slavka Krautzeka 83/A \\ 51000 Rijeka, Croatia \\ Phone: +385 (51) 770447 \\ Fax: +385 (51) 686166 \\ www.intechopen.com
}

\author{
InTech China \\ Unit 405, Office Block, Hotel Equatorial Shanghai \\ No.65, Yan An Road (West), Shanghai, 200040, China \\ 中国上海市延安西路65号上海国际贵都大饭店办公楼 405 单元 \\ Phone: +86-21-62489820 \\ Fax: $+86-21-62489821$
}


(C) 2011 The Author(s). Licensee IntechOpen. This chapter is distributed under the terms of the Creative Commons Attribution-NonCommercialShareAlike-3.0 License, which permits use, distribution and reproduction for non-commercial purposes, provided the original is properly cited and derivative works building on this content are distributed under the same license. 